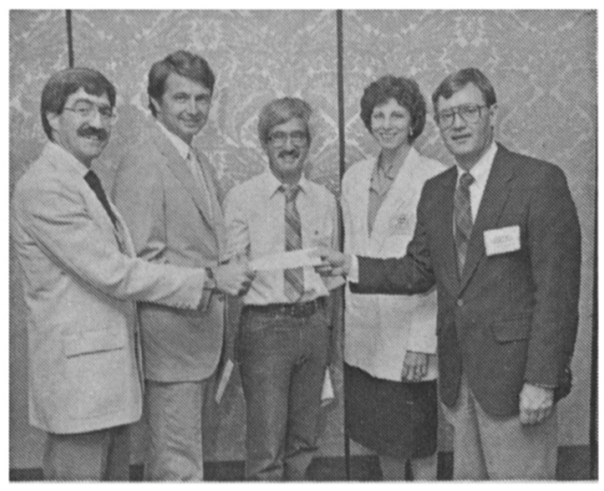

Stephen Frantzich (r. to 1.) and Diana Evans present 1988 Fenno Award to John Ferejohn, Bruce Cain and Morris Fiorina.

Fiorina showed us how to study constituency service, and how to understand its effects.

They argue further that the electoral connection is critical to legislative policy-making. As a result of the substantial personal vote in these two, single member district systems, the legislatures are more fragmented and decentralized than they would be if voters were motivated solely by partisan considerations. Public policy in the two systems is therefore more particularistic.

The Fenno competition for 1989 will include books published at any point during the 1988 calendar year, and will be judged by a Fenno Prize Committee made up of Morris Fiorina of Harvard University, Chairman, and Gerhard Loewenberg of the University of lowa and Professor Suzanne Parker of Florida State University. Authors and others interested are invited to nominate outstanding 1988 books in legislative studies for the Fenno Prize by arranging for publishers to submit three copies of such works to the Fenno Prize Committee. One copy is to be sent to each member of the Committee listed above by March 1. 1989. Authors of prospective nominated books should consult with their publishers to ensure that copies are so sent. The 1989 Richard F. Fenno, Jr. Prize will be announced and conferred at the 1989 Awards Ceremony of the Legislative Studies Section held during and in conjunction with the annual meeting of the American Political Science Association in Atlanta.
The Fenno prize honors the outstanding scholarship of Richard F. Fenno, Jr. of the University of Rochester, the leading contemporary analyst of legislative studies and the 1984-85 President of the American Political Science Association.

\section{Urban Politics and Urban Policy Section Presents Awards}

The APSA organized section on Urban Politics and Urban Policy made the following awards at the 1988 Annual Meeting in Washington, DC:

Norton E. Long, first recipient of the Urban Politics and Policy Career Achievement Award for 1988.

Edward C. Banfield, Special Award for Contributions to Urban Political Theory.

Todd Swanstrom, State University of New York at Albany, Best Book in Urban Politics written during the past five years, for The Crisis of Growth Politics: Cleveland, Kucinich, and the Challenge of Urban Populism (Temple University Press, 1985).

Stephen Elkin, University of Maryland, Best Book in Urban Theory written in the past five years for City and Regime in the American Republic (University of Chicago Press, 1987).

Martin Shefter, Cornell University, Best Book in Urban Policy award for 1988. His book, Political Crisis, Fiscal Crisis: The Collapse and Revival of New York City (Basic Books, 1985) was judged the best urban policy book in the last five years.

\section{Washington Gathering and Book Honor James MacGregor Burns}

During the APSA annual meeting 150 friends gathered to honor James Mac- 
Gregor Burns on the occasion of his seventieth birthday. A surprise book of essays, entitled Essays in Honor of James MacGregor Burns was presented to Professor Burns.

Co-edited by historian Michael R. Beschloss and political scientist Thomas E. Cronin, the volume contains a dozen essays about leadership, the presidency, party renewal, and accountable constitutional government--several of the major themes Burns has written about in his nearly 50 years of teaching and research. Contributors include Hedrick Smith, Richard Morris, James David Barber, Benjamin Barber, Barbara Kellerman, Kay Lawson, Donald Robinson, Jack Peltason, Otis L. Graham, and Philippa Strum as well as Michael Beschloss and Tom Cronin. Published by Prentice-Hall, the book can be ordered by writing Prentice-Hall, Englewood Cliffs, NJ 07632 (\$20, clothbound).

In his comments at the gathering, Professor Cronin noted that "we come together to celebrate our friendship and respect for jim Burns, as he turns 70 years old, a colleague, teacher, mentor and friend-cherished as much for his unfailing generosity as for his compelling analyses of power, leadership and politics in America." He added: "We salute Professor Burns this evening for his 50 years of teaching and writing with faith, idealism, clarity and moral passion." "He has warned us that power wielded justly today may be wielded corruptly tomorrow and has

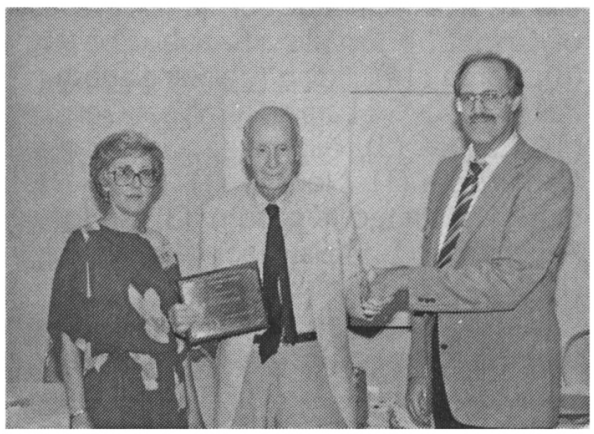

Norton E. Long became the first recipient of the Career Achievement Award. $L$. to $r$., Bryan Jones, chair of the Award Committee; Norton Long; and Barbara Burt-Way, president of the Urban Politics Section.

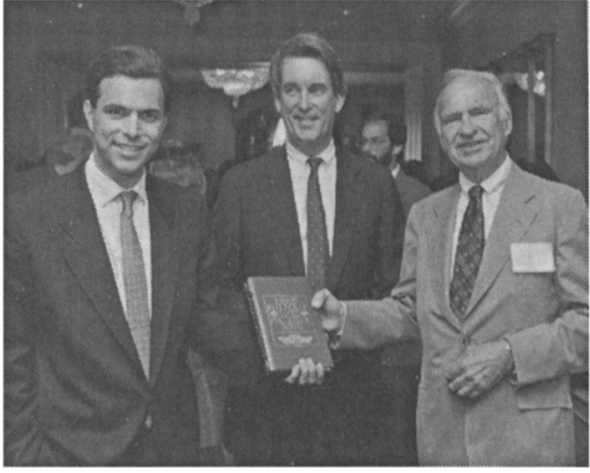

James MacGregor Burns (r.) receives a book of essays published in his honor from Thomas $E$. Cronin and Michael R. Beschloss.

urged us to honor the framers of the Constitution by doing what they would do if they were here today-to rethink, debate and question our procedures for governance and leadership." Cronin quoted from C. Vann Woodward's observations about one of Burns' major books that it "struck a telling blow at both the American political tradition itself and at all the scholarly and public complacency about

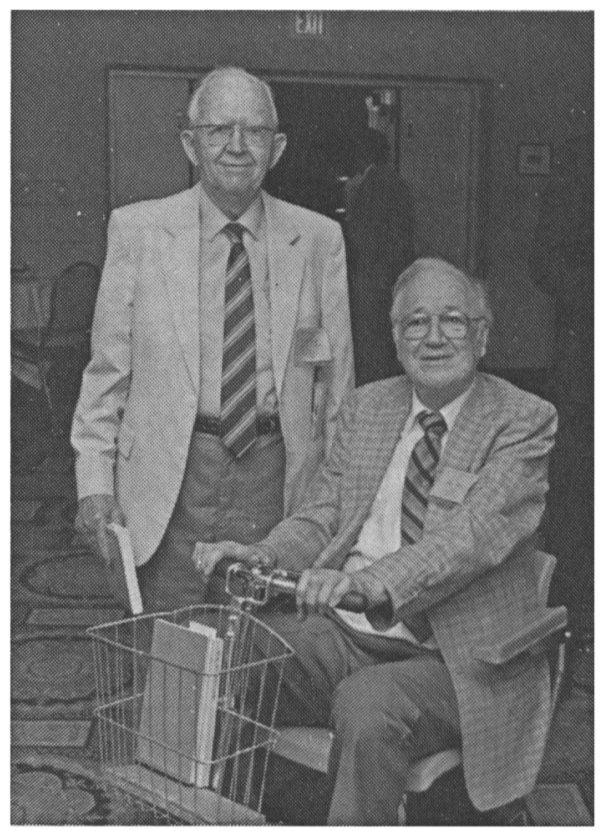

C. Herman Pritchett and Frank P. Bourgin at the University of Chicago's reception. 
that tradition" and he noted that above all else, Jim Burns had rejected pragmatism, complacency, and moral evasion as he searched for more effective ways to encourage moral leadership and effective governance for our political system.

Historian Michael R. Beschloss, a former student of Burns' at Williams, observed that "As President of the American Political Science Association and the International Society for Political Psychology, he has brought meaning to the word colleague and has been notably generous to younger scholars. Teaching political science for four decades at his beloved Williams College, it might be said, he has never treated a student simply as a student." Beschloss added: "Recitation of Jim's careers as scholar, activist, academic leader, and teacher does nothing to convey his decency, curiosity, zeal, iconoclasm, and steadfastness to principle. This volume of essays by twelve of his friends and colleagues is to honor him on his seventieth birthday. . . . All of the essays reflect our pleasure to know him and our satisfaction in his singular place in American scholarship, letters, teaching, and politics."

\section{Bourgin Attends Annual Meeting}

Frank P. Bourgin was among the over 4,000 political scientists who attended the Washington Annual Meeting. Bourgin received national attention when after 43 years the University of Chicago's Department of Political Science reversed itself by accepting his doctoral thesis and awarded Bourgin his Ph.D. at the age of 77.

Bourgin's dissertation argues that the New Deal was firmly rooted in the activist federal government envisioned by the framers of the U.S. Constitution. In 1945 when Bourgin submitted his dissertation for approval it was universally held that the framers of the Constitution had envisioned a laissez-faire government. The Chicago Department rejected Bourgin's thesis, and Bourgin left the University without realizing his goal of securing a Ph.D.

Bourgin's academic career took a sudden turn for the better when historian Arthur Schlesinger, to whom Bourgin had. sent a synopsis of his rejected dissertation, encouraged Chicago's department to reconsider Bourgin's work. Bourgin's dissertation was accepted and is scheduled for publication later this year.

This year Bourgin was named an honorary Life Member of APSA.

\section{Foreign Students Attend 1988 APSA and IPSA Meetings with Grant Support}

Through funds provided by the Institute for International Education, The Asia Foundation, and the German Marshall Fund of the United States, 60 foreign graduate students studying political science in the United States were given grants to help pay for their travel expenses to the IPSA 14th World Congress and the 1988 APSA Annual Meeting. Of the 61 awards, 24 were funded by the Institute for International Education; 35 by the Asia Foundation; and 2 by the German Marshall Fund.

Students from 23 countries were among the grantees. The country distribution of the awards included: Burma (1), Republic of China (6), People's Republic of China (8), Korea (14), Japan (2), Bangladesh (2), Pakistan (1), Sri Lanka (1), West Germany (3), Canada (3), Nigeria (2), Ethiopia (1), Cameroons (I), Norway (1), Italy (1), Jordan (1), United Kingdom (3), India (4), Argentina (I), El Salvador (1), Nicaragua (I), Iran (I), and Mexico (2).

Listed below are the recipients with their country of origin and current institution.

\section{IIE Travel Grantees}

Konrad Stenzel, West Germany; Yale University

Geoffry B. Robinson, Canada; Cornell University 